\title{
Tourist Experience: How Does Revisit Intention Impact Brand Value Destinations?
}

\author{
Rahyuniati Setiawan $^{1}$, Asep Saepuloh ${ }^{2}$, Anggun Oktavia Herlianti ${ }^{3}$ \\ Universitas Garut, Jalan Raya Samarang No.52A, Garut ${ }^{1,2,3}$
}

\begin{abstract}
Understanding the needs of tourists and then utilizing it into a marketing strategy and making the brand value (brand value) high compared to its competitors, the strategy of creating value from customers is a managerial key and a long-term benefit. The research objective of analyzing tourist experience on revisit intention and its impact on destination brand value is to obtain findings regarding the effect of tourist experience on revisit intention and its impact on destination brand value. This research was conducted at the largest hot spring tourist attraction in Garut Regency. The research method used is the verification research method, using SEM and in quantitative research data analysis is carried out after the data of all respondents are collected.The results of this study indicate that there is an effect of tourist experience on revisit intention and has an impact on brand value destinations.
\end{abstract}

Keywords: Tourist Experience, Revisit Intention, Brand Value Destinations.

\section{Introduction}

Although experts discuss that brand value is an essential condition for economic development, there is still consensus on economic growth models that take brand value into account [1]. Managers must understand the needs of tourists to use it as a marketing strategy [2]. The intention of returning visits is one of the key managerial benefits, even the intention of returning visits is one of the key components of loyal tourists so that it has an impact on long-term benefits [3]. Garut Regency has a variety of tourist attractions, including natural tourism, cultural tourism (historical tourism and pilgrimage), agro tourism, and special interest tourism. This is the choice of visitors to travel to Garut Regency.

Based on data from DISBUDPAR Garut Regency, 2018 shows the level of visits at Cipanas Tourism Object, which ranks first is the Sabda Alam Water Park with 103,080 visitors. Based on the research background that has been described. There is a growing interest in the value and management of intangible assets especially brands, as the business environment becomes more complex than ever. As the battle for customers intensifies every day, companies are too willing to have strong brands [4]. Brand value destination from tourists is an important study for the success of tourist objects to progress and develop. Revisit intention, if neglected, will reduce tourists purchasing decisions for their products, experiencebased products are not identical to service-based products even though there are overlapping areas [5]. Every company is founded with a specific purpose so that it can survive and thrive. One of the company's goals is to increase the level of profit or profit of the company. The urgency of this research is that as a hot spring tourism destination, it has stimulated the growth 
of the hot water tourism market, so that an understanding of revisit intention and brand value for tourists is important for managers of hot water tourism development so that the marketing strategy of the trip is targeted and effective. This research is included in the focus of national research, namely social humanities - arts and culture - education, the theme of economic studies and human resources, the topic of entrepreneurship, cooperatives and SMEs.

\section{Methodology}

The research method used is descriptive and verification research methods. This method describes the object of research based on existing and ongoing facts by collecting, compiling and explaining the data required for later analysis according to existing theories. Descriptive research in this study aims to obtain an overview of the tourist experience at the Largest Hot Spring Tourism Object in Garut Regency, an overview of revisit intention, and an overview of brand value. Verification research basically wants to test the truth of a hypothesis carried out through data collection in the field, wherein this study will be tested whether what is done by the Largest Hot Spring Tourism Object in Garut Regency to increase tourist experience so that it affects revisit intention and has an impact on brand value.

The research method is designed to make it easier for researchers to make conclusions. The method used is information from some of the data obtained such as data on the growth of tourist visits to the largest hot spring tourist attraction in Garut Regency, data on visitors to tourist objects in Garut district and data on visits to the Largest Hot Springs Tourism Objects in Garut Regency with the aim of know the opinion of a part of the population on the object being studied. The method used in the data collection technique is a questionnaire, which contains questions about the identity and experience of the respondent, the respondent's assessment of tourist experience, revisit intention and brand value. Literature study, with secondary data collection by studying books and journals to obtain information related to theories and concepts related to research problems. Interview, by asking questions both written and oral, both to the manager of the hot water tourism object of visitors in Garut Regency and to tourists visiting Cipanas Garut. As well as observations, researchers come directly to tourist destinations. The hot spring tourist object is the most crowded tourist in Garut Regency and the Department of Tourism and Culture of Garut Regency to obtain the necessary data.

\section{Result and Discussion}

\subsection{Structural Model Analysis Results}

The measurement model on the lower order explains the manifest variables that are correlated with the construct dimension (outer loading) along with the p-value as the level of significance. The results of the measurement model on its higher order explain the value of the path coefficients between the dimensional construct and its variables and the p-value as the level of significance. 


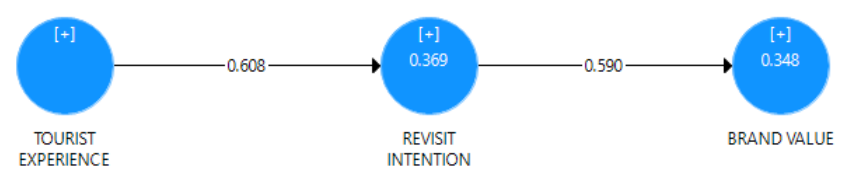

Fig.1. Structural Model Analysis

All indicators are significant in measuring the latent variable $(\mathrm{p}<0.001)$ and have the factor weight coefficient above the minimum required value of 0.70 . Judging from the AVE statistics, the test results show that the five measurement models provide an AVE value greater than 0.50 and statistically significant $(\mathrm{p}<0.001)$. This means that all indicators used to measure the latent variables under study have sufficient convergent validity. Judging from the value of Cronbach's Alpha and composite reliability, the test results show that the value of Cronbach's Alpha and composite reliability for the five measurement models is significant ( $\mathrm{p}$ $<0.001$ ) with a value above the minimum required value of 0.70 . This indicates that the five measurement models have adequate internal reliability. The result show at table 1.

Table 1. Convergent Validity and Reliability of the Measurement Model

\begin{tabular}{|c|c|c|c|c|c|}
\hline \multirow{3}{*}{$\begin{array}{c}\text { Convergent } \\
\text { Validity }\end{array}$} & \multicolumn{3}{|c|}{ Convergent Validity } & \multicolumn{2}{|c|}{ Reability } \\
\hline & \multirow[t]{2}{*}{ Indicator } & Outer Loadings & AVE & $\begin{array}{c}\text { Cronbach's } \\
\text { Alpha }\end{array}$ & $\begin{array}{c}\text { Composite } \\
\text { Reability }\end{array}$ \\
\hline & & $>0.70$ & $>0.50$ & $>0.70$ & $>0.70$ \\
\hline \multirow[t]{4}{*}{ TE } & TE1 & 0.865 & 0.757 & 0.894 & 0.926 \\
\hline & TE2 & 0.854 & & & \\
\hline & TE3 & 0.876 & & & \\
\hline & TE4 & 0.886 & & & \\
\hline \multirow[t]{3}{*}{ RI } & RI1 & 0.769 & 0.699 & 0.856 & 0.903 \\
\hline & RI2 & 0.865 & & & \\
\hline & RI3 & 0.839 & & & \\
\hline \multirow[t]{5}{*}{ BV } & BV1 & 0.781 & 0.614 & 0.844 & 0.888 \\
\hline & BV2 & 0.796 & & & \\
\hline & BV3 & 0.758 & & & \\
\hline & BV4 & 0.762 & & & \\
\hline & BV5 & 0.818 & & & \\
\hline
\end{tabular}

Judging from the results of the cross loadings analysis, all indicators used to measure the five measurement models indicate that the value of the factor weight coefficient (outer loadings, typed in bold) is greater than the value of the cross loadings. This shows that the five measurement models have sufficient discrete validity. Objective information is obtained that, judging from the Fornell-Larcker criteria, the five measurement models have a square root value of AVE that is greater than the correlation coefficient between the measured constructs and other constructs. That is, the five measurement models are indicated to have adequate discriminated validity. In line with the test results above, seen from the coefficient of heterotrait-monotrait ratio (HTMT), it is found that the five measurement models have sufficient discrete validity. This is shown by the HTMT statistics for the ten pairs of measurement models compared to all of them, giving HTMT values below the required 
maximum value of 0.85 or 0.90 . In addition, at a $95 \%$ confidence level, the bootstrapping estimation results provide confidence intervals and / or confidence intervals for the bias corrected HTMT statistics for all ten pairs of measurement models that are compared, none of which give a number of one. According to Hair et.al (2017: 122) if: "The confidence interval of the HTMT statistic should not include the value 1 for all cons of constructs", this indicates that the measurement model has sufficient discriminant validity.

Table 2. Construction Between Variables

\begin{tabular}{cccccc}
\hline & $\begin{array}{c}\text { Table 2. Construction Between Variables } \\
\text { Original } \\
\text { Sample (O) }\end{array}$ & $\begin{array}{c}\text { Sample Mean } \\
(\mathbf{M})\end{array}$ & $\begin{array}{c}\text { Standard } \\
\text { Deviation } \\
\text { (STDEV) }\end{array}$ & $\begin{array}{c}\text { T } \\
\text { Statistical } \\
(\mid / \text { STDEV } \mid \text { ) }\end{array}$ & $\begin{array}{c}\text { P } \\
\text { Values }\end{array}$ \\
\hline $\begin{array}{c}\text { Revisit Intention - } \\
>\text { Brand Value }\end{array}$ & 0.590 & 0.598 & 0.040 & 14.619 & 0.000 \\
\hline $\begin{array}{c}\text { Tourist } \\
\text { Experience }->\end{array}$ & 0.608 & 0.614 & 0.040 & 15.122 & 0.000 \\
Revisit Intention & & & & & \\
\hline
\end{tabular}

Source: Output Bootstrapping.

Referring to the overall evaluation results of the measurement model above, it can be concluded that the sample data set that was successfully collected through the TE, RI, and BV measurement models is valid and reliable for use in subsequent data analysis, namely testing structural models or testing hypotheses research. The following is a tabulation of the results of testing the structural equation model as a full model which will be described based on its substructure show at table 2. Value is an assessment of consumers on the benefits obtained from the consumption of a product / service relative to the costs sacrificed [6]. This means that the difference between the total utility that consumers get and the total cost they pay for a product / service is a reflection of value [7]. Rationalize the relative nature of quality prices and underline the fact that consumers not only look at the price of a product, but also judge the price based on perceived quality, competitors' offerings, their own opportunity costs, and other such issues. as a convenience and a social / psychological factor is a value concept [8]. Brand value is useful as a key in building the image of a product made by the public and potential tourists for a destination and this image has a positive influence on destination selection. [9] Value is conceptualized as a dynamic and subjective construct that determines the volume of gain and loss or loss by tourists or travelers in different situations [10]. Social value comes from the intense interaction of the people in it allowing an understanding of the social value of space as a process and recognizing dynamics. relationship between the place and the people visiting the destination [11].

The importance of revisit intention comes from the quality experience of the destination [12]. Revisit intention to a destination will be influenced by the image of the destination itself, as well as promotional efforts and marketing distribution of the destination object so that the destination image is one of the factors that influence revisit intention [13]. Further factors involved in evaluating revisit intention include intention to recommended and positive word of mouth [14]. A visitor's revisit intention to a destination will be affected by the appearance of the destination. Revisit Intention is seen as an extension of satisfaction rather than initiating the process of making a repeat visit request [8]. Revisit intention is an intention to return which refers to an individual's subjective assessment of personal actions or specific actions or consumer behavior that can apply to target attitudes [15]. This explains revisit intention is the result of tourist experience so that a positive tourist experience will make tourists come back or revisit intention. 
The behavior of tourists has an important role for a company because if a company wants to grow and develop, management must know the needs and desires of tourists (Reid and Bojanic, 2009). Tourist experience is the result of the interaction of the destination, the tourism system, society and other tourists [16]. Destination is an important aspect in shaping the tourist experience [17]. Three stages that influence each other for the construct and form of tourism experiences, namely pre-visit, during visit, and post-visit stages [18]. The dimensions of tourist experience are divided into four, namely, entertainment, educational, esthetic, and escape, depending on the form of consumer involvement in the experience [19]. entertainment experiences are characterized as a combination of consumer passive participation and absorption, whereas educational experiences are characterized as a combination of active participation and absorption. On the other hand, esthetics is characterized as a combination of immersion and passive participation, while escape is characterized as a combination of immersion and active participation [20].

\section{Conclusion}

Based on the results of research that has been carried out from the results of the discussion on the analysis of tourist experience on revisit intention and its impact on brand value destinations, a survey of the most popular tourist attractions in Garut Regency can be concluded that the sample data set that was successfully collected through the TE, RI, and BV measurement models is valid and reliable for use in subsequent data analysis, namely testing structural models or testing hypotheses research. The results of this study indicate that there is an effect of tourist experience on revisit intention and has an impact on brand value destinations. Based on the research results obtained from the findings that have been produced, the authors provide suggestions or recommendations as follows with the hope of providing input for the progress and development of the management of hot water attractions in Garut Regency. This study proves that there is a significant influence between tourist experience on tourist revisit intention. But besides that, this research also shows that there are still problems that must be considered by the management of hot water attractions in Garut Regency. The recommendation of the author is to increase the novelty element of hot water tourism objects in Garut Regency, both through added tourist activities and tourists visiting hot water attractions in Garut Regency not only enjoying natural hot water and others but there are other activities that provide new experiences for tourists. So that it will increase the desire of tourists to return to the hot spring tourist attraction in Garut Regency in the future.

\section{Acknowledgements}

We are thank to the Directorate of Research and Community Service, Directorate General of Research Strengthening and Research, Technology and Higher Education Research, which has funded the research of novice lecturers which was carried out within 1 year.

\section{References}

[1] N. Zeynep, E. Yolbulan, Ü. Arslan, and M. Özgür, "The effect of brand value on economic growth : A multinational analysis,” Eur. Res. Manag. Bus. Econ., vol. 25, no. 
1, pp. 1-7, 2019, doi: 10.1016/j.iedeen.2018.11.002.

[2] C. H. S. Liu and T. Lee, "Service quality and price perception of service: Influence on word-of-mouth and revisit intention," J. Air Transp. Manag., vol. 52, pp. 42-54, 2016, doi: 10.1016/j.jairtraman.2015.12.007.

[3] M. Marinkovic, V., Senic, V., Ivkov, D., Dimitrovski, D., \& Bjelic, "The antecedents of satisfaction and revisit intentions for full-service restaurants," Mark. Intell. Plan., vol. 32, no. 3, pp. 311-327, 2014, doi: 10.1108/02634501011078138.

[4] S. D. M. M, B. Merrilees, and D. Miller, "Brand management to protect brand equity : A conceptual model," J. Brand Manag., vol. 17, no. 8, pp. 605-617, 2010, doi: 10.1057/bm.2010.15.

[5] K. Hung, N. Peng, and A. Chen, "Incorporating on-site activity involvement and sense of belonging into the Mehrabian-Russell model - The experiential value of cultural tourism destinations," Tour. Manag. Perspect., vol. 30, no. February, pp. 43-52, 2019, doi: 10.1016/j.tmp.2019.02.003.

[6] J. Luo, B. L. Dey, C. Yalkin, U. Sivarajah, and K. Punjaisri, "Millennial Chinese

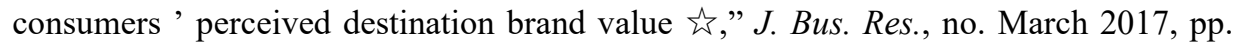
0-1, 2018, doi: 10.1016/j.jbusres.2018.06.015.

[7] S. Franco and C. Cicatiello, The Role of Food Marketing in Increasing Awareness of Food Security and Sustainability: Food Sustainability Branding, vol. 3. Elsevier, 2018.

[8] L. Wu, K. Chen, P. Chen, and S. Cheng, "Perceived value , transaction cost , and repurchase-intention in online shopping: A relational exchange perspective," J. Bus. Res., vol. 67, no. 1, pp. 2768-2776, 2014, doi: 10.1016/j.jbusres.2012.09.007.

[9] M. Jabreel, A. Moreno, and A. Huertas, "Journal of Destination Marketing \& Management Semantic comparison of the emotional values communicated by destinations and tourists on social media," J. Destin. Mark. Manag., pp. 1-14, 2016, doi: 10.1016/j.jdmm.2016.03.004.

[10] A. Al-ansi and H. Han, "Journal of Destination Marketing \& Management Role of halal-friendly destination performances, value , satisfaction , and trust in generating destination image and loyalty," J. Destin. Mark. Manag., vol. 13, no. May 2019, pp. 51-60, 2020, doi: 10.1016/j.jdmm.2019.05.007.

[11] S. L. Wearing and C. Foley, "Annals of Tourism Research Understanding the tourist experience of cities," Ann. Tour. Res., vol. 65, pp. 97-107, 2017, doi: 10.1016/j.annals.2017.05.007.

[12] H. Bulus and E. M. Samdi, "Discriminant Analysis of Tourist Revisit-Intention for Effective Marketing of Ecotourism Destinations in Plateau State .," vol. 12, no. 3, pp. 63-70, 2016, doi: 10.9790/5728-1203076370.

[13] J. E. Bigné, I. Sánchez, L. Andreu, and I. Sa, “The role of variety seeking in short and long run revisit intentions in holiday destinations," 2014, doi: 10.1108/17506180910962113.

[14] S. Sanz-Blas, D. Buzova, and E. Carvajal-Trujillo, "Familiarity and visit characteristics as determinants of tourists' experience at a cruise destination," Tour. Manag. Perspect., vol. 30, no. July 2018, pp. 1-10, 2019, doi: 10.1016/j.tmp.2019.01.005.

[15] Y. Wang, S. H. Hsiao, Z. Yang, and N. Hajli, “The impact of sellers' social influence on the co-creation of innovation with customers and brand awareness in online communities," Ind. Mark. Manag., vol. 54, pp. 56-70, 2016, doi: 10.1016/j.indmarman.2015.12.008.

[16] W. Tan, "Journal of Destination Marketing \& Management Repeat visitation : A study from the perspective of leisure constraint, tourist experience, destination images, and 
experiential familiarity," J. Destin. Mark. Manag., no. 2013, pp. 1-10, 2016, doi: 10.1016/j.jdmm.2016.04.003.

[17] R. Daneshvary and R. K. Schwer, "The association endorsement and consumers' intention to purchase," J. Consum. Mark., vol. 17, no. 3, pp. 203-213, 2000, doi: 10.1108/07363760010328987.

[18] E. Halpenny, S. Kono, and F. Moghimehfar, "Predicting World Heritage site visitation intentions of North American park visitors," J. Hosp. Tour. Technol., vol. 9, no. 3, pp. 417-437, 2018, doi: 10.1108/JHTT-10-2017-0109.

[19] M. A. Jones, K. E. Reynolds, M. J. Arnold, C. B. Gabler, S. T. Gillison, and V. M. Landers, "Exploring consumers' attitude towards relationship marketing," J. Serv. Mark., vol. 29, no. 3, pp. 188-199, 2015, doi: 10.1108/JSM-04-2014-0134.

[20] H. J. Song et al., "The Influence of Tourist Experience on Perceived Value and Satisfaction with Temple Stays: The Experience Economy Theory the influence of tourist experience on perceived value and satisfaction with temple stays: the experience economy," no. February 2015, pp. 37-41, 2014, doi: 10.1080/10548408.2014.898606. 